\title{
Lightning and electrical activity during the Shiveluch volcano eruption on 16 November 2014
}

\author{
Boris M. Shevtsov ${ }^{1}$, Pavel P. Firstov ${ }^{1,2}$, Nina V. Cherneva ${ }^{1}$, Robert H. Holzworth ${ }^{3}$, and Renat R. Akbashev ${ }^{2}$ \\ ${ }^{1}$ Institute of Cosmophysical Research and Radio Wave Propagation FEB RAS, Paratunka, Kamchatskii krai, Russia \\ ${ }^{2}$ Kamchatka Branch of the Geophysical Service of RAS, Petropavlovsk-Kamchatskii, Kamchatskii krai, Russia \\ ${ }^{3}$ Earth and Space Sciences, University of Washington, Seattle, USA
}

Correspondence to: N. V. Cherneva (nina@ikir.ru)

Received: 3 September 2015 - Published in Nat. Hazards Earth Syst. Sci. Discuss.: 4 November 2015

Accepted: 1 March 2016 - Published: 29 March 2016

\begin{abstract}
According to World Wide Lightning Location Network (WWLLN) data, a sequence of lightning discharges was detected which occurred in the area of the explosive eruption of Shiveluch volcano on 16 November 2014 in Kamchatka. Information on the ash cloud motion was confirmed by the measurements of atmospheric electricity, satellite observations and meteorological and seismic data. It was concluded that WWLLN resolution is enough to detect the earlier stage of volcanic explosive eruption when electrification processes develop the most intensively. The lightning method has the undeniable advantage for the fast remote sensing of volcanic electric activity anywhere in the world. There is a good opportunity for the development of WWLLN technology to observe explosive volcanic eruptions.
\end{abstract}

\section{Introduction}

The atmospheric electricity variations during volcano explosive eruptions indicate the eruptive clouds' electrification which may be the result of magma fragmentation and formation of an eruptive column (James et al., 1998, 2003; Mather and Harrison, 2006; Thomas et al., 2008), ash differentiation or may involve ice-ice interaction from the rapidly expanding and cooling water vapor of the volcano (Williams and McNutt, 2005; McNutt and Williams, 2010). Whatever the detailed cause of volcanic ash cloud charge separation, volcano explosive eruptions are powerful sources of lightning. Thus, ash clouds, posing a threat to aviation and to the surrounding area, may be identified within seconds by a lightning location system, even in conditions of poor visibility.
At present, the World Wide Lightning Location Network (WWLLN) is capable of recording lightning discharges with the timing accuracy of a few microseconds, which makes it possible to determine the location of discharges with the accuracy of a few kilometers anywhere in the world (Hutchins et al., 2012; Rodger et al., 2006; Ewert et al., 2010; Lane et al., 2011).

The electricity efficiency of any volcano may be estimated retrospectively by considering long-term WWLLN data. Even weak volcanic eruptions may be accompanied by lightning activity (McNutt and Williams, 2010).

Eruptive cloud electrification also affects the atmospheric electric field variations (James et al., 2003). During the Shiveluch volcano eruption, a fluxmeter was used to measure atmospheric electric field variations, and WWLLN was used for locating the lightning as reported on the WWLLN website (http://wwlln.net/volcanoMonitor.html). Moreover, to determine the beginning of the eruption, seismic data were plotted, and to observe the eruptive cloud motion, satellite images were applied. Cloud motion velocity and direction were compared with meteorological data.

\section{Methods of observations}

Data on the location of lightning discharges accompanying the eruption are available on the website: http://wwlln.net. The Kamchatka WWLLN site is installed at Paratunka.

During the explosive eruption of the Shiveluch andesitic volcano $\left(56^{\circ} 47^{\prime} \mathrm{N}, 157^{\circ} 56^{\prime} \mathrm{E}\right)$ on 16 November 2014 , a fluxmeter, EF-4, was used to measure the atmospheric electric field variations. The fluxmeter is installed at the KZY 


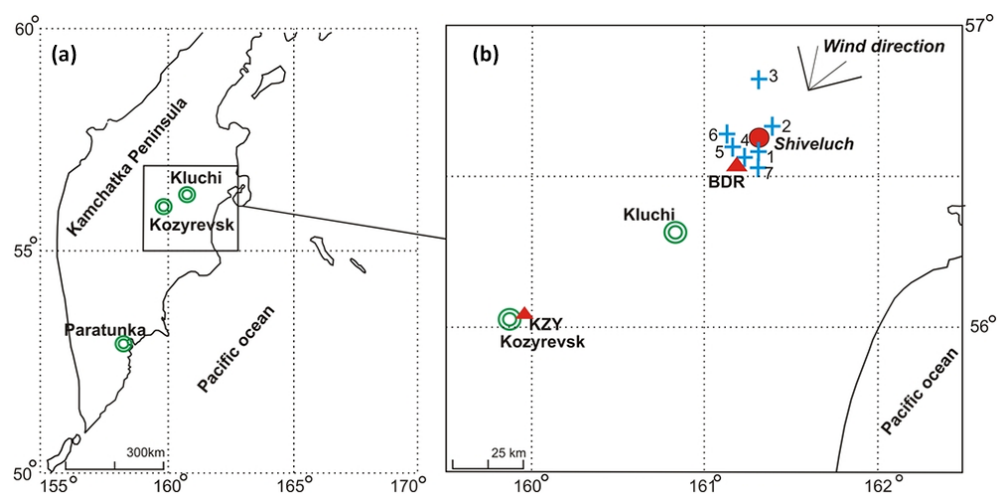

Figure 1. The Shiveluch volcano, observation sites (Kozyrevsk city - KZY), Kluchi and BDR - Seismic station Bajdarnaja) and locations of lightning (1-7).

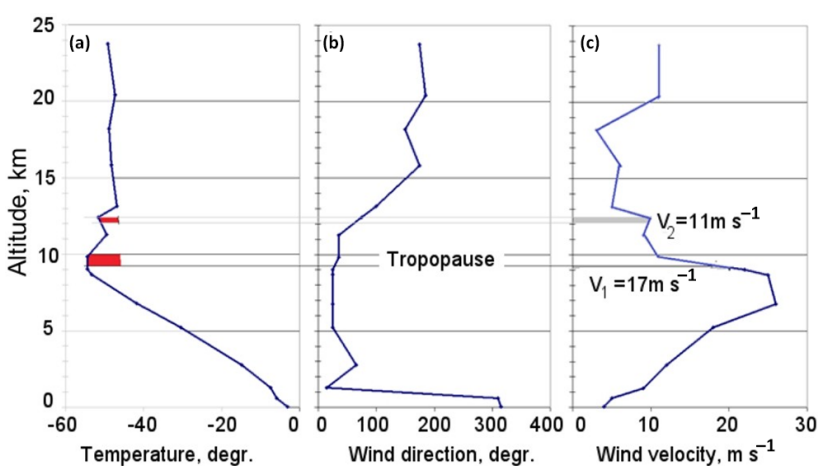

Figure 2. Vertical profiles of temperature (a), wind direction (b) and wind velocity (c) according to the data of Kluchi meteorological observatory at 12:00 UT on 16 November 2014.

seismic station (Fig. 1) of Kamchatka Branch of the Geophysical Service of the Russian Academy of Sciences (RAS). This station is located at $113 \mathrm{~km}$ to the southwest of Shiveluch volcano and at $50 \mathrm{~m}$ of altitude above sea level (Fig. 1). Meteorological parameters were recorded at KZY by the Vaisala WXT520 weather station.

The eruption was accompanied by an explosive earthquake which was recorded by seismic stations located at $10 \mathrm{~km}$ to the southwest of Shiveluch volcano at the BDR site (Fig. 1).

The Kluchi meteorological observatory is located at $48 \mathrm{~km}$ to the southwest of Shiveluch volcano (Fig. 1) and is maintained by the Kamchatka Department for Hydrometeorology and Environmental Control. The meteorological data of this station (atmospheric pressure, air temperature, humidity and balloon sounding of the atmosphere twice per day) are available on the website: http://www.esrl.noaa.gov/raobs/ intl/intl2000.wmo.

According to the weather balloon sounding on 16 November 2014 at 12:00 UT, temperature and wind profiles up to $25 \mathrm{~km}$ in height are shown in Fig. 2. There are two temperature inversions at $9-10$ and $12 \mathrm{~km}$ in height, where wind velocities were 17 and $11 \mathrm{~m} \mathrm{~s}^{-1}$, respectively. At these alti-

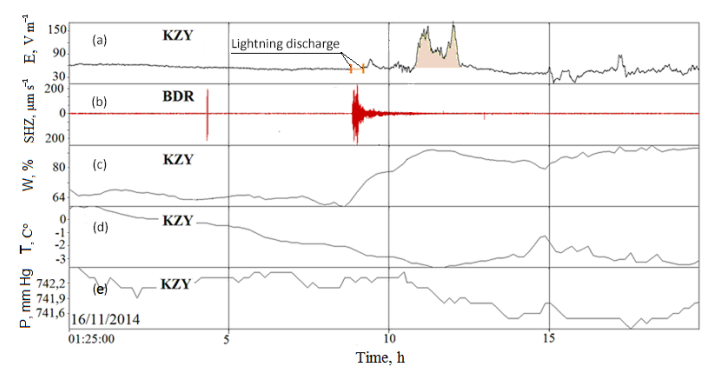

Figure 3. Electric field E at the KZY site (a); seismic signal SHZ (short period vertical component of seismic signal) at the BDR site accompanied the Shiveluch volcano eruption on 16 November 2014 (b); meteorological parameters at the KZY site (c, d, e). The beginning of the timescale is 01:25:00 UT. The time interval of lightning activity is shown in (a).

tudes, the wind direction was approximately toward southwest (azimuths were 50 and $80^{\circ}$; Fig. 2b). The direction is opposite to the azimuth. The height of the lower inversion corresponded to the tropopause that is typical for the fallwinter period in the Kamchatka Peninsula.

\section{Evolution of the eruptive plume}

The onset of the eruption was determined with the accuracy of up to several seconds by the onset of the explosive earthquake which was recorded at BDR seismic station near the volcano, at 10:17:55 UT (Table 1).

The WWLLN recorded seven discharges near the volcano; their times are shown in Table 1 and their locations are shown in Fig. 1b. Within the interval from $1 \mathrm{~min} 21 \mathrm{~s}$ to $1 \mathrm{~min} 39 \mathrm{~s}$ after the onset of the eruption, three discharges were recorded. The next three discharges were recorded almost simultaneously at $8 \mathrm{~min} 22 \mathrm{~s}$ after the eruption onset. The last occurrence of lightning was at $18 \mathrm{~min} 15 \mathrm{~s}$ after the eruption onset. The time interval from $1 \mathrm{~min} 21 \mathrm{~s}$ to $18 \mathrm{~min}$ 
Table 1. Chronology of observations of Shiveluch volcano eruption on 16 November 2014.

\begin{tabular}{|c|c|c|c|c|c|c|c|c|}
\hline & & & \multirow[t]{2}{*}{ Time, UT } & \multicolumn{2}{|c|}{ Coordinates } & \multirow{2}{*}{$\begin{array}{r}R, \\
\mathrm{~km}\end{array}$} & \multirow{2}{*}{$\begin{array}{c}V \\
\mathrm{~ms}^{-1}\end{array}$} & \multirow[t]{2}{*}{ Notes } \\
\hline & & & & $\varphi, \mathrm{N}$ & $\lambda, \mathrm{E}$ & & & \\
\hline 1 & $\begin{array}{l}\text { Arrival of a seismic } \\
\text { signal at BDR }\end{array}$ & & $10: 17: 55.3$ & & & & & \\
\hline \multirow{7}{*}{2} & \multirow{7}{*}{ Volcanic lightning } & 1 & 10:19:16.1 & 56.58 & 161.31 & 2.7 & & \\
\hline & & 2 & 10:19:26.7 & 56.67 & 161.38 & 4.5 & & \\
\hline & & 3 & $10: 19: 33.8$ & 56.82 & 161.31 & 8.9 & & \\
\hline & & 4 & $10: 26: 22.6$ & 56.56 & 161.23 & 10.9 & & \\
\hline & & 5 & $10: 26: 22.6$ & 56.60 & 161.17 & 10.8 & & \\
\hline & & 6 & $10: 26: 22.6$ & 56.64 & 161.13 & 11.9 & & \\
\hline & & 7 & $10: 36: 10.2$ & 56.53 & 161.31 & 20.5 & & \\
\hline \multirow{3}{*}{3} & \multirow{3}{*}{ Satellite images } & 1 & $10: 40$ & & & & & Landsat 8 \\
\hline & & 2 & $11: 45$ & & & & & Modis \\
\hline & & 3 & $12: 00$ & & & & & MTSAT-IR \\
\hline \multirow{2}{*}{4} & \multirow{2}{*}{$\begin{array}{l}\text { Electric field disturbances } \\
\text { at the KZY site }\end{array}$} & 1 & $12: 04$ & & & 113.0 & 17.7 & \\
\hline & & 2 & $13: 10$ & & & 113.0 & 10.9 & \\
\hline
\end{tabular}

In the table, $R$ is the distance passed by the cloud from the volcano extrusive dome; $V$ is the average velocity of the cloud front.

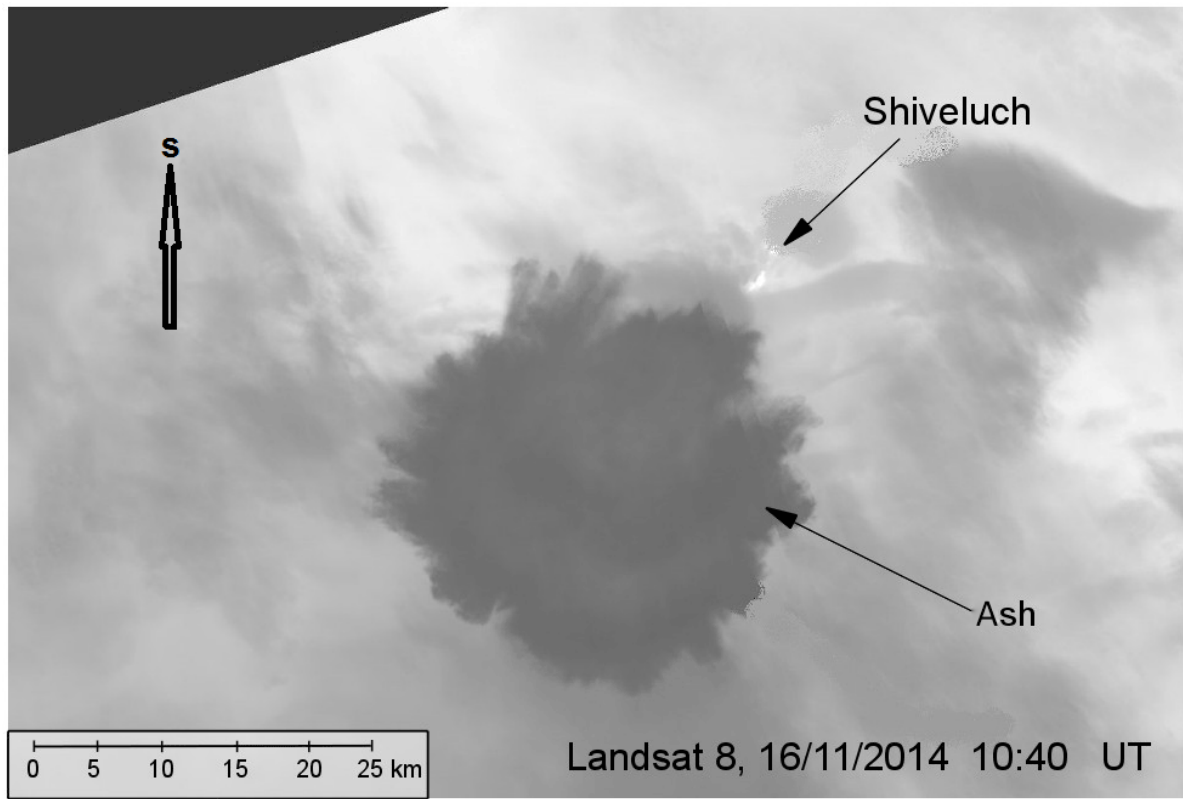

Figure 4. Satellite image (Landsat 8) of the eruptive cloud, at 10:40 UT on 16 November 2014.

$15 \mathrm{~s}$ corresponds to plume lightning activity. The seismic signal is shown to decrease (Fig. 3).

All lightning activity occurs around the volcano at distances of not more than $10 \mathrm{~km}$, but most occurs to the southwest of the crater (Fig. 1b). This distribution may be a result of wind changes with the increase in altitude (Fig. 2b).

A satellite image (Landsat 8), taken at 22 min after the onset of the eruption (Table 1, Fig. 4) shows the shape and the position of the eruptive cloud. As with the WWLLN data, the satellite image confirms the motion of the ash cloud to the southwest.

This result was confirmed by the satellite images of the Moderate Resolution Imaging Spectrometer (MODIS) and Multi-functional Transport Satellite (MTSAT-IR) systems which were obtained at 11:45 and 12:00 UT, respectively. These images are not shown here and may be available as part of the data sets of the named systems. 
The MODIS satellite image shows two fronts of the ash cloud at 104.3 and $71.7 \mathrm{~km}$ to the southwest of the volcano. This result corresponds to the weather data if it is supposed that the ash cloud propagated at 9 and $12 \mathrm{~km}$ of altitude with the different velocities (Table 1, Fig. 2).

According to the MTSAT-IR satellite image obtained at 12:00 UT, the Volcanic Ash Advisory Center in Tokyo concluded that an eruptive cloud was at $9 \mathrm{~km}$ of altitude above sea level, moving to the southwest at a velocity of about $15 \mathrm{~m} \mathrm{~s}^{-1}$. This result corresponds to the weather data (Table 1, Fig. 2).

At KZY, the background value of the atmospheric electric field was about $60 \mathrm{~V} \mathrm{~m}^{-1}$ before the eruption and increased after eruption (Fig. 3a). When two fronts of the ash cloud arrived at the KZY site, strong disturbance of the atmospheric electric field took place. At this time, the meteorological parameters did not show significant variations (Fig. 3c-e). Observations of electric field supplement the monitoring of the lightning.

\section{Conclusions}

The Kamchatka volcano group is located near populated areas and international air routes. Due to this, explosive eruptions are serious threats to their security. To decrease the risks, effective systems for remote detection of eruptions are necessary. WWLLN resolution is enough for the remote sensing of the volcano lightning activity in the early stage of the ash cloud formation during some minutes after the eruption when electrification proceeds the most intensively. The development of the regional WWLLN segment provides good opportunities; the observation accuracy may be increased. The undeniable advantage of the WWLLN method is its possibility to be used in conditions of poor visibility. Moreover, from the analysis, not only of signal arrival times, but also of the signal structure and its comparison with electric, acoustic and meteorological data, it is possible to obtain information on the characteristics and tendencies of ash cloud motion.

Acknowledgements. The authors thank E. R. Williams and C. Cimarelli for useful comments. This publication was supported by US Civilian Research \& Development Foundation grant RUG17084_PA-13 and Far Eastern Branch of Russian Academy of Sciences grant CRDF-14-007. The authors wish to thank the World Wide Lightning Location Network (http://wwlln.net), a collaboration among over 50 universities and institutions, for providing the lightning location data used in this paper.
Edited by: G. Macedonio

Reviewed by: E. Williams and C. Cimarelli

\section{References}

Ewert, J. W., Holzworth, R. H., and Diefenbach, A. K.: Global detection of explosive volcanic eruptions with the World Wide Lightning Location Network (WWLLN) and application to aviation safety, Invited paper, American Geophysical Union, Fall Meeting, December 2010, San Francisco, abstract \#AE31A-04, 2010.

Hutchins, M. L., Holzworth, R. H., Rodger, C. J., and Brundell, J. B.: Far field power of lightning strokes as measured by the World Wide Lightning Location Network, J. Tech. (AMS), 29, 1102-1110, 2012.

James, M. R., Lane, S. J., and Gilbert, J. S.: Volcanic plume monitoring using atmospheric electrical potential gradients, J. Geol. Soc. Lond., 155, 587-590, 1998.

James, M. R., Lane, S. J., and Gilbert, J. S.: Density, construction, and drag coefficient of electrostatic volcanic ash aggregates, J. Geophys. Res., 108, 2435, 2003.

Lane, S. J., James, M. R., and Gilbert, J. S.: Electrostatic phenomena in volcanic eruptions, J. Phys., 301, 012004, doi:10.1088/1742-6596/301/1/012004, 2011.

Mather, T. A. and Harrison, R. G.: Electrification of volcanic plumes, Surv. Geophys., 27, 387-432, doi:10.1007/s10712-0069007-2, 2006.

McNutt, S. R. and Williams, E. R.: Volcanic lightning: global observations and constraints on source mechanisms, Bull. Volcanol., 72, 1153-1167, 2010.

Rodger, C. J., Werner, S., Brundell, J. B., Lay, E. H., Thomson, N. R., Holzworth, R. H., and Dowden, R. L.: Detection efficiency of the VLF World-Wide Lightning Location Network (WWLLN): initial case study, Ann. Geophys., 24, 31973214, doi:10.5194/angeo-24-3197-2006, 2006.

Thomas, R. J., McNutt, S. R., Krehbiel, P., Rison, W., Aulich, G., Edens, H., Tytgat, G., and Clark, E.: Lightning and Electrical Activity during the 2006 Eruption of Augustine Volcano, in: The 2006 Eruption of Augustine Volcano, Ch. 25, US Geological Survey, Alaska, 579-608, 2008.

Williams, E. R. and McNutt, S. R.: Total water contents in volcanic eruption clouds and implications for electrification and lightning, in: Chapter 6 in Recent Progress in Lightning Physics, edited by: Pontikis, C., Research Signpost Publishing, Kerala, India, 81-93, 2005. 